\title{
The Relationship between Price, Lead Time, and Delay toward the Order Quantity in Steel Manufacturer
}

\author{
Julie Wijaya, Purwanto* \\ Faculty of Economics, President University, Bekasi, Indonesia \\ *Corresponding Author: purwanto@president.ac.id
}

Copyright $(2013$ Horizon Research Publishing All rights reserved.

\begin{abstract}
In the manufacturing, purchasing is one of the important departments due to upwards of $60 \%$ of cost comes from parts and material purchasing. Reliable and trustworthy suppliers are a vital link in an effective purchasing process. Beside quality and price, timely deliveries of goods or services are one which can be contributed by supplier for the effective operations, especially in raw materials. This research is conducted to investigate the relationship between price, lead time, and delay toward the order quantity in steel manufacturer at PT. Chunpao Steel Indonesia (CPS), Karawang, West Java, Indonesia. By analyzing the relationship, the researcher will gain enough information for the most factor which influencing the decision in raw material purchasing for PT. CPS. The study adopted the theory of purchasing and business buyer behavior, using a quantitative method for investigate and analysis the relationship between three independent variables : price, lead time, delay toward the dependent variables, order quantity. The research samples are consisting of 42 incoming shipments from period of May 2009 until June 2012. Data were tested with classic assumption test, and analyzed by the multiple linear regressions, which the statistical hypothesis is tested using t-test and F-test with the level of significance is set at $5 \%$. Based on the analysis result, it be found that only price has a significant relationship to the order quantity. The coefficient of determination of this research is 0.191 , which mean that $19.1 \%$ of order quantity can be explained by price, lead time, and delay, while the rest for $80.9 \%$ is explained by other factors that not examined.
\end{abstract}

Keywords Purchasing, order quantity, price, lead time, delay

\section{Introduction}

Purchasing is a department which responsible for obtaining the materials, parts, supplies, and services which needed for producing a product or provide a service for the organization's customers. Purchasing is a link between an organization and its suppliers. Purchasing as a part from supply chain management is one of the importance departments in the manufacturing company, due to upwards of $60 \%$ of the cost of finished goods comes from parts and material purchasing. Nonetheless, the importance of purchasing is more than just the cost of goods purchased, other important factors beside the quality of goods, is the services and the timing of deliveries, both of these can have a significant impact on operations. (Stevenson, J. Williams, 2005).

The goal of purchasing is to develop and implement purchasing plans for products and services that support the operation strategies. One of the important of these interfaces in the purchasing department is suppliers. Reliable and trustworthy suppliers are a vital link in an effective purchasing process. Timely deliveries of goods or services and high quality are just two of the ways that suppliers can contribute to effective operations, especially in raw materials. The decision of the purchased goods not also depend on one factor, it also can be influenced by some other factors. Buyer behavior especially in the business or manufacturing can be influenced not only by one single factor, it also can be stimulated by the environment, and the organization itself.

According to the data of purchasing department PT. CPS, the outlook of the quantity suppliers from 2009 until June 2012 is in the increasing pattern, as shown in below figure: 


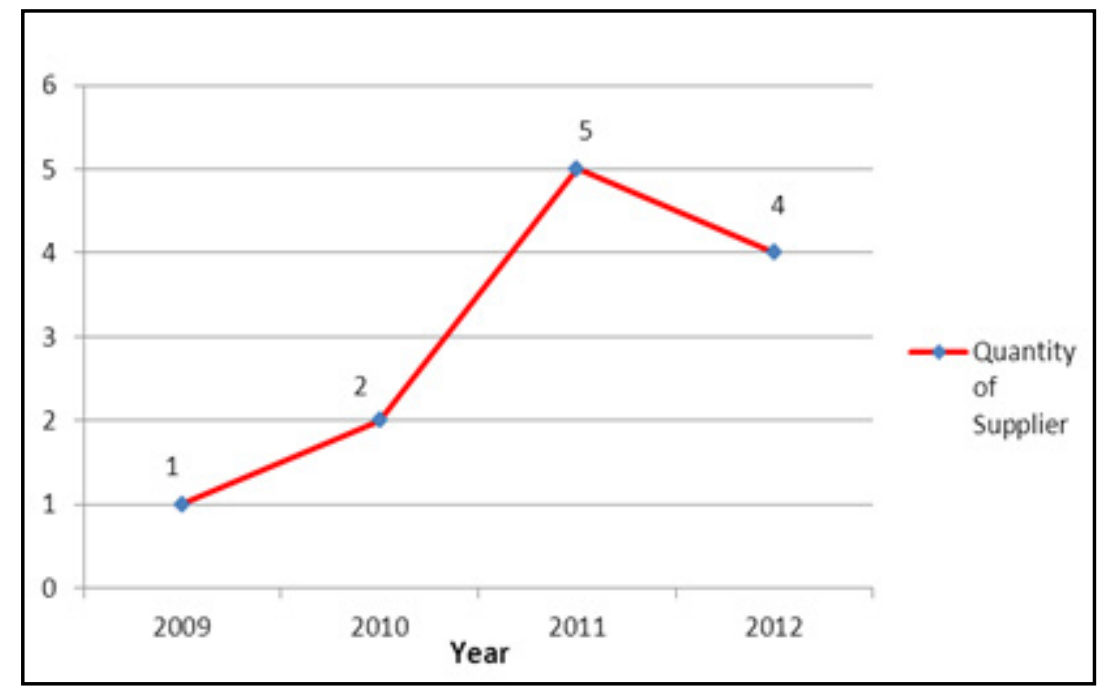

Source : Purchasing Department PT. CPS

Figure 1. Quantity of Suppliers

The graph shows that the total suppliers for the material is only one supplier in the period time from May - December 2009, and be increased to be two suppliers in 2010. In 2011 the suppliers for raw material has increased to be five suppliers, while for January until June 2012 the supplier has been four. The graph pattern shows that in 2010 the company is starting looking other suppliers, starting for not depending only by the single supplier. The company tries to find some other suppliers who can compete for the best advantage, and the most minimum risk or disadvantage for the company. The outlook of the percentage from each supplier for the period May 2009 until June 2012 was shown as below figure :

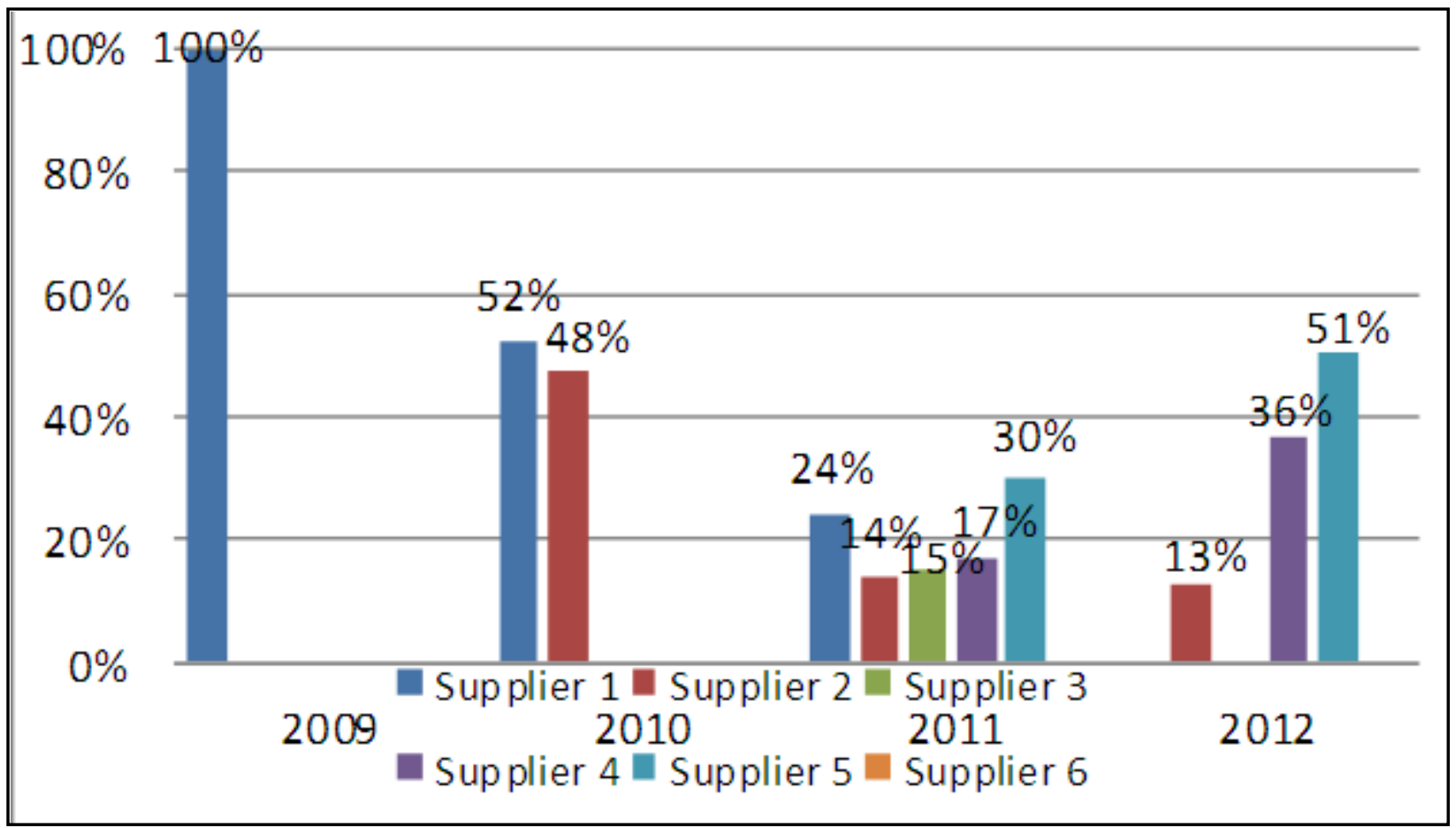

Source : Purchasing Department PT. CPS

Figure 2. Percentage of Suppliers Order

The above graph shows for the order quantity which be placed to each suppliers in the period of May 2009 until June 2012. In period of May - December 2009 the purchasing of raw material was be focused on one supplier which mean the percentage is $100 \%$, but in 2010 the company placed the raw material to two suppliers with the percentage of each supplier is: $52 \%$ and $48 \%$, in 2011 the company placed the order to five different suppliers, with the percentage of each supplier is $24 \%, 14 \%, 15 \%, 17 \%$, and $30 \%$. In the period of January until June 2012 the percentage of three suppliers are: 
$13 \%, 36 \%$, and $51 \%$. Based on this fact, the researcher would like to find what factors are influencing the management decision for buying the material beside the quality factors, in order to get the reference for future improvement in choosing the suppliers.

In the manufacturing company, purchasing is one of the important department due to upwards of $60 \%$ of the cost of finished goods comes from parts and material purchasing, and in the steel manufacturer the material itself already got the percentage around $60 \%$ from the sales price, which mean it is very important for the purchasing department in order to choose the best supplier which can fulfill the customer requirement, with the best cost for the company.

The data from May 2009 until June 2012 shows that the suppliers in PT. CPS was increased from year to year, it shows that PT. CPS still looking for the new supplier or trying to find the best supplier for accomplish the goals of the company. The researcher would like to know for this several years what is the considering factor in management of PT. CPS to choose the supplier, for the future improvement.

This research is about determining the most factors that contribute to the purchasing decision of the order quantity for the material in PT. CPS. Thus, according to the company's background, the problem can be formulated as follow: a). Are there any relationship between price, lead time, and delay toward order quantity in PT. CPS ?

b). How far is the relationship between price, lead time, and delay toward order quantity in PT. CPS ?

The objective of this research is to discover the relationship between price, lead time, and delay toward the order quantity, and how far does the price, lead time, and delay affect the order quantity of raw material in PT. CPS. By analyzing the relationship, the researcher will gain enough information to understand the current situation of purchasing decision in PT. CPS, and can give the suggestion for the improvement. Based on the following aim and the consideration of several limitations, it is advisable to approach the problems with quantitative methods.

\section{Literature Review and Key Concepts}

\section{Business Buyer Behavior}

Business Buyer Behavior is the activities in the business which directly involved in obtaining, consuming, and disposing of products and services, including the decision processes that precede and follow these actions. The model of business buyer behavior was shown as below :

\begin{tabular}{|c|c|c|c|}
\hline \multicolumn{2}{|c|}{ The environment } & \multirow{2}{*}{ The buying organization } & Buyer responses \\
\hline \multirow{2}{*}{$\begin{array}{l}\text { Marketing } \\
\text { stimuli }\end{array}$} & Other & & \multirow{7}{*}{$\begin{array}{c}\text { Product or service choice } \\
\text { Supplier choice } \\
\text { Order quantities } \\
\text { Delivery terms and times } \\
\text { Service terms } \\
\text { Payment }\end{array}$} \\
\hline & & 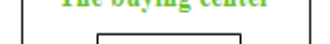 & \\
\hline Product & Economic & Buying & \\
\hline Price & Technological & $\begin{array}{l}\text { decision } \\
\text { process }\end{array}$ & \\
\hline Place & Political & (Internersonal and & \\
\hline & Cultural & individual influences) & \\
\hline & Competitive & (Organizational influences) & \\
\hline
\end{tabular}

Source : Philip Kotler, Gary Armstrong (2010), Principles of Marketing

Figure 3. The Model of Business Buyer Behavior

In this model, marketing and other stimuli affect the buying organization and produce certain buyer responses. Marketing stimuli consist of the four Ps : product, price, place, and promotion. Other stimuli include major forces and events in the buyer's environment: economic, technological, political, cultural, and competitive. These stimuli enter the organization and are turned into buyer responses. Within the organization, buying activity consists of two major parts: the buying center, made up of all the people involved in the buying decision, and the buying decision process. The model shows that the buying center and the buying decision process are influenced by internal organizational like interpersonal, and individual factors as well as by the external environmental factors.

\section{Order Quantity}

Order quantity is a confirmed request quantity by one party to another party to buy, sell, deliver, or receivegoods or services under specified terms and conditions. When accepted by the receiving party, an order becomes a legally bindingcontract. This order quantity will be shown in the purchase order which mean a legal document between buyer and the suppliers. After selecting suppliers, the buyer will negotiates the final order, the quantity needed, the expected time of delivery, the specifications, and so on. The quantity of the purchased order will also depends on the company fear. Companies that fear a shortage of key materials are willing to buy in a large quantity, and willing to hold large inventories. This company will sign long term contracts with suppliers to ensure a steady flow of materials. Some customers are not willing to hold large inventories; they let their supplier take this responsibility, like just in time. 


\section{Price}

Price is the amount of money charged for a product or service. It is the sum of all the values that customers give up to gain the benefits of having or using a product or service. It is one of the most important elements determining a firm's market share and profitability. Price is the one element of "four Ps" in the marketing mix. Marketing mix is the set of controllable, tactical marketing tools that the firm blends to produce the response it wants in the target market. Each price charged leads to a different level of demand.

\section{Lead Time}

Lead Time is an estimate of the time between releasing an order and receiving that order. Accuracy in lead times is very important because early or late orders can greatly affect other items and production schedules. For purchased items, the lead time is the estimated time for the supplier to prepare or produce the order plus shipping time. Lead times are usually assigned based on past history and discussion with the supplier, often the lead time is agreed to in a purchasing contract. It is important that lead times be tracked over time. If a supplier is consistently late or early, either the lead time should be changed or a discussion with the supplier on how to improve lead times should be conducted for the time between the placed order and the expected time for arriving.

For items that are manufactured or produced within the company, the lead time must take into account a number of factors, including:

a) Setup Time

b) Processing Time

c) Materials Handling Time

d) Waiting Time

Every step that a part follows in the manufacturing process involves each of these times, thus an estimate must be made for each.

\section{Delay}

Delay is the condition of delivery which be late than the promised. It was directed to the delivery. Delivery itself is refers to how well the product or service is delivered to the customer. It includes speed, accuracy, and care attending the delivery process. The speed and reliability with which a product or service is delivered is another area in which companies can be distinguished. The time of delivery refers to the gap between when a customer orders a product and when he or she receives it. Delay delivery can also affect the production condition, and the delivery performance to the customer.

\section{Research Model and Hypothesis}

\subsection{Theoretical Framework}

The framework explains what researcher aims to find out in this study. By using problem in purchasing department of PT. CPS as the background, this study intends to find out the relation between order quantity and price, lead time, and delay toward the order quantity which be explained as follow:

a). Order Quantity (Y) is the quantity that placed or ordered to a supplier.

b). Price $\left(X_{1}\right)$ is the amount of money charged for a product or service.

c). Lead Time $\left(\mathrm{X}_{2}\right)$ is an estimate time between order releasing and order receiving.

d). Delay $\left(\mathrm{X}_{3}\right)$ is the lateness for the delivery time which has been promised by the supplier when a customer orders a product.

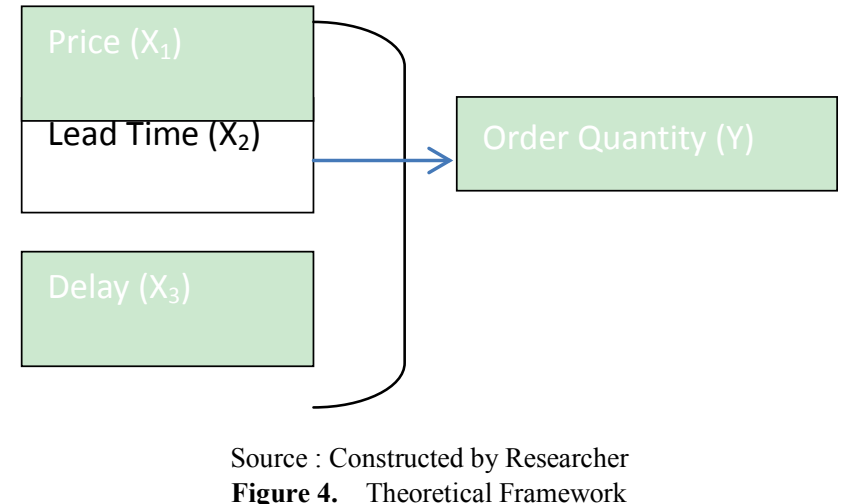

The dependent variable is order quantity $(\mathrm{Y})$. The independent variable is the factors which affect or determine the order quantity, which consisted of price (X1), lead time (X2), and delay (X3).

\subsection{Hypothesis}

The Hypothesis in this research is :

a) There is relationship between price toward order quantity in PT. CPS.

b) There is relationship between lead time toward order quantity in PT. CPS.

c) There is relationship between delay toward order quantity in PT. CPS.

Determine hypothesis formulation

$\mathrm{Ho}_{1}$ : Price $\left(\mathrm{X}_{1}\right)$ has no significant relationship toward order quantity in the purchased of raw material in PT. Chunpao Steel Indonesia.

$\mathrm{Ha}_{1}$ : Price $\left(\mathrm{X}_{1}\right)$ has a significant relationship toward order quantity in the purchased of raw material in PT. Chunpao Steel Indonesia.

$\mathrm{Ho}_{2}$ : Lead Time $\left(\mathrm{X}_{2}\right)$ has no significant relationship toward order quantity in the purchased of raw material in PT. Chunpao Steel Indonesia.

$\mathrm{Ha}_{2}$ : Lead Time $\left(\mathrm{X}_{2}\right)$ has a significant relationship toward order quantity in the purchased of raw material in PT. Chunpao Steel Indonesia.

$\mathrm{Ho}_{3}$ : Delay $\left(\mathrm{X}_{3}\right)$ has no significant relationship toward order quantity in the purchased of raw material in PT. ChunpaoSteel Indonesia.

$\mathrm{Ha}_{3}$ : Delay $\left(\mathrm{X}_{3}\right)$ has a significant relationship toward order 
quantity in the purchased of raw material in PT. Chunpao Steel Indonesia.

\subsection{Multiple regression analysis}

The data in this research is more than two variables, thus the researcher uses multiple regressions as the statistical tool for analyzing the data. Multiple linear regression analysis is a statistic method to analyze how far or how strong does the relationship between the independent variables and dependent variable. The general descriptive form of multiple regression equation is shown below:

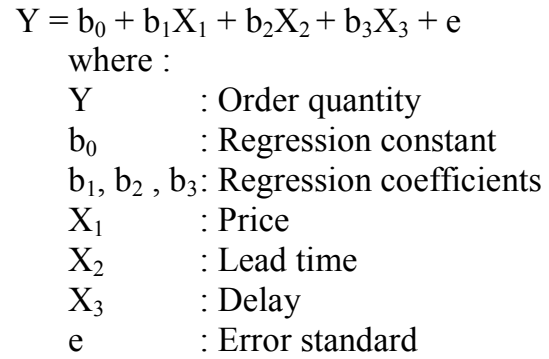

a. t-test

A t-test is used to determine whether there is a significant relationship between independent,

i. If the significance value ( $\mathrm{p}$ value) which be counted $>$ 0.05 , then $\mathrm{HO}$ is accepted and Ha is rejected.

ii. If the significance value ( $\mathrm{p}$ value) which be counted $<$ 0.05 , then $\mathrm{HO}$ is rejected and $\mathrm{Ha}$ is accepted.

Table 1. Coefficient of Regression Model

Coefficients $^{\mathrm{a}}$

\begin{tabular}{|c|c|c|c|c|c|}
\hline \multirow[t]{2}{*}{ Mortal } & \multicolumn{2}{|c|}{ Unstandardized Coefficients } & $\begin{array}{l}\text { Standardized } \\
\text { Coefficients }\end{array}$ & \multirow[t]{2}{*}{$\mathrm{t}$} & \multirow[t]{2}{*}{ Sig } \\
\hline & B & Std. Error & Beta & & \\
\hline 1 (Constant) & 454.244 & 111.091 & & 4089 & .000 \\
\hline X1 (Price) & -.380 & .128 & -.478 & -2.973 & 005 \\
\hline X2 (Lead Time) & -.502 & .484 & -.174 & -1.036 & .307 \\
\hline X3 (Delay) & -.710 & 1090 & -.106 & -652 & .518 \\
\hline
\end{tabular}

a. Dependent Variable: V (Order Quantity)

Source : SPSS 17.0

The mathematical model for this research is :

$\mathrm{Y}=454.244-0.380 \mathrm{X}_{1}$

The constant of 454.244 indicates that if the price is stable $\left(X_{1}=0\right)$, lead time was not over from the standard $\left(\mathrm{X}_{2}=0\right)$, and no delay $\left(\mathrm{X}_{3}=0\right)$, then the quantity of the order will be $454.244 \mathrm{M} / \mathrm{T}$. This quantity order is the total order of material purchasing.

a. t-test

A $\mathrm{t}$ - test is used to determine whether there is a significant relationship between independent variables and dependent variables partially. Based on the calculation as per table 4.5, the results are below :

iPrice $\left(\mathrm{X}_{1}\right)$ has t-value of -2.973 (negative), and the $\mathrm{p}$-value of 0.005 , which less than 0.05 ( $\left.\mathrm{p}<0.05\right)$, then $\mathrm{H} 0$ is rejected, Ha is accepted, which means the independent variable of price $\left(\mathrm{X}_{1}\right)$ has a significant relationship in the opposite direction of the dependent variable of order quantity $(\mathrm{Y})$. Based on that comparison it can be concluded that price $\left(\mathrm{X}_{1}\right)$ has a significance relationship (negative) to order quantity $(\mathrm{Y})$.

iiLead Time $\left(\mathrm{X}_{2}\right)$ has t-value of -1.036 (negative), and p-value of 0.307 , which more than 0.05 ( $\mathrm{p}>0.05$ ), then $\mathrm{H} 0$ is accepted, Ha is rejected, which means the independent variable of lead time $\left(\mathrm{X}_{2}\right)$ has no significant relationship to the dependent variable of order quantity $(\mathrm{Y})$.

iiiDelay $\left(\mathrm{X}_{3}\right)$ has t-value of -0.652 (negative), and the $\mathrm{p}$-value of 0.518 , which more than 0.05 ( $\left.\mathrm{p}>0.05\right)$, then $\mathrm{H} 0$ is accepted, 
Ha is rejected, which means the independent variable of delay (X3) has no significant relationship to the dependent variable of order quantity (Y).

b. F - test

F-test is used to determine whether there is a significant linear relationship between the dependent variable and independent variables. The result of F-test for this research is shown in the Analysis of Variance (ANOVA) table as below:

Table 2. F-test (ANOVA)

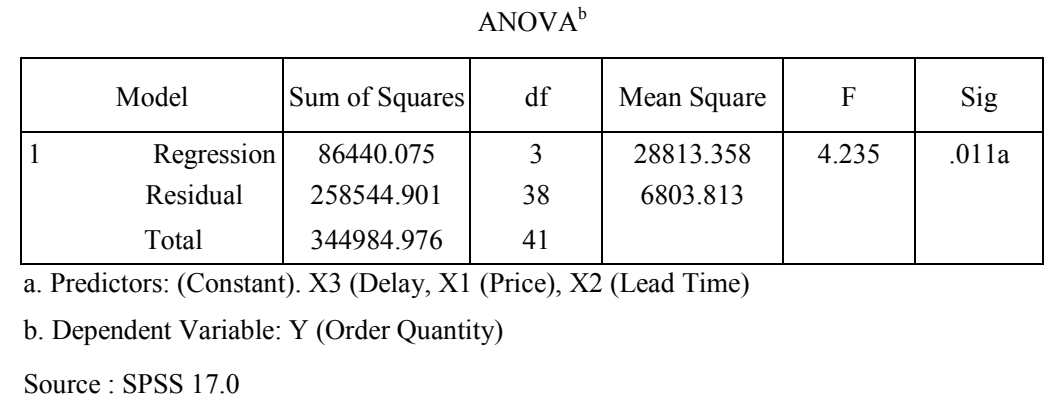

The value of $F$ statistic is 4.235 with significance level 0.011 which less than $0.05(\mathrm{p}<0.05)$, thus the null hypothesis (Ho) is rejected, in other word, there is a relationship between order quantity $(\mathrm{Y})$ and price $\left(\mathrm{X}_{1}\right)$, lead time $\left(\mathrm{X}_{2}\right)$, and delay $\left(\mathrm{X}_{3}\right)$.

Coefficient of determinationor $\mathrm{R}^{2}$ is the contribution of all independent variables which have effects to the dependent variable in percentage. The contribution of all independent variables to the dependent variables that used in this research is shown below:

c. Coefficient of Determination $\left(\mathrm{R}^{2}\right)$

Table 3. Coefficient of Determination $\left(\mathrm{R}^{2}\right)$

\begin{tabular}{|c|c|c|c|c|}
\hline Model & $\mathrm{R}$ & R Square & $\begin{array}{c}\text { Adjusted R } \\
\text { Square }\end{array}$ & $\begin{array}{c}\text { Std. Error of the } \\
\text { Estimate }\end{array}$ \\
\hline 1 & $.501 \mathrm{a}$ & .251 & .191 & 82.48523 \\
\hline
\end{tabular}

a. Predictors: (Constant). X3 (Delay). X1 (Price), X2 (Lead Time)

The $\mathrm{R}$ is 0.501 shows of a moderate regression coefficient between the predictors (price, lead time, and delay) and dependent variable (order quantity). The adjusted $\mathrm{R}^{2}$ is 0.191 indicates that price, lead time, delay altogether have a $19.1 \%$ contribution to affect order quantity, the rest $80.9 \%$ is explained by other variables or factors.

As the researcher observation, the other variables or factors of this $80.9 \%$ is as follow:

a) PT. CPS is a group company, which the decision is also be taken by the group management member.

b) The other factor which be considered by PT. CPS when choosing the supplier is consider about the business line of the supplier, whether the supplier has their own group which is supplying the same goods with PT. CPS to the customers.

It is also shown in the table that the standard error of estimate (SEE) is 82.48523. This SEE value indicates whether a regression model can be used as predictor or not by comparing the SEE value to the standard variance. If the SEE is lesser than standard variance, then the regression model can be used as predictor. In this case, the standard deviation for order quantity $(\mathrm{Y})$ shown in the descriptive statistics is 91.72932 , which mean the SEE is less than the standard variance $(82.48523<91.72932)$. Thus, this regression model can be used as a predictor of quantity order.

\section{Conclusions}

a) By partially price has a significant relationship toward order quantity. The relation is a negative relationship. Each increase of USD 1 of the material price will affect the order quantity decrease for 0.380 M.T. If the price was stable (not increasing), the order quantity should be 454.244 M.T, when the increasing price reach USD 1,195.38, then the order quantity will be zero. It was follow the price and demand relation by Philip Kottler, which state that in the normal case, demand and price are inversely related, the higher the price, the lower the demand. In short, consumers with limited budgets probably will buy less of something if its price is too high.

b) By partially the variable lead time and delay have no significant relationship toward order quantity. They can be showed from the significant value of lead time and delay. The significance value of lead time and delay have not compiled the requirement to become a significant relationship

c) By altogether, price, lead time, and delay have relationship toward order quantity. The contribution of price, lead time, and delay toward the order quantity is $19.1 \%$. The remaining of $80.90 \%$ is caused by the influence of other variables that are not included in the research model.

\section{REFERENCES}


[1] Engel, James F., Blackwell, Roger D., \&Miniard, Paul W.R. (1995). Consumer Behavior. Texas: The Dryden Press.

[2] Hariwijaya, M. \& Triton, P.B. (2011). PedomanPenulisanIlmiahSkripsidanTesis. Jakarta: PT SukaBuku.

[3] Heizer, Jay \& Render, Barry. (1998). Production and Operations Management. Massachusetts: Allyn and Bacon.

[4] Kottler, Philip., Keller, Kevin Lane., Ang, SweeHoon., Leong, SiewMeng., Tan, Chin Tiong. (2006). Marketing Management. Singapore: Pearson Prentice Hall.

[5] Kottler, Philip. \& Armstrong, Gary. (2010). Principles of Marketing. Singapore: Pearson Prentice Hall.

[6] Lind, Marchal, Wathen. (2010). Statistical Techniques in Business and Economics. America :McGraw Hill.

[7] Murphy, Paul R., \& Wood, Donald F. (2004). Contemporary Logistics. New Jersey: Pearson Prentice Hall.

[8] PriyatnoDuwi. (2009). 5 Jam BelajarOlah Data dengan SPSS 17. Jakarta: CV Andi Offset.

[9] Render, Barry., Stair, Ralph., M. Hanna., Michael E. (2006). Quantitative Analysis for Managament. America : Pearson Prentice Hall.
[10] Santoso, Singgih. (2012). PanduanLengkap SPSS Versi 20. Jakarta: PT Elex Media Komputindo.

[11] Santoso, Singgih. (2012). Aplikasi SPSS padaStatistikParametrik. Jakarta: PT Elex Media Komputindo.

[12] SantosoSinggih. (2010). StatistikMultivariat. Jakarta: PT Elex Media Komputindo.

[13] Stevenson, William (2005), Operation Management, $8^{\text {th }}$ Edition, Amerika: McGraw-Hill/Irwin

[14] Verma., Boyer., Kenneth, Rohit. (2012). Operations \& Supply Chain Management. United States : South Western Language Learning.

[15] Cheraghi, S. Hossein, Dadashzadeh, Mohammad, Subramanian, Muthu. (2008). Critical Success Factors for Supplier Selection : An Update, vol.20, p.92-93.

[16] Tahriri. Farzad, Osman. M. Rasid, Ali Aidy, Moh. Yusuf. Rosnah, Esfandriary. Alireza. (2008). AHP approach for supplier evaluation and selection in a steel manufacturing company, vol. 01, p.56-57.

[17] http://en.wikipedia.org

[18] http ://www.businessdirectory. com 